\title{
EDITORIAL
}

\section{Environmental and occupational risk factors associated with different pathological conditions}

\author{
SALVATORE SANTO SIGNORELLI ${ }^{1}$ and MARGHERITA FERRANTE ${ }^{2}$ \\ Departments of ${ }^{1}$ Clinical and Experimental Medicine, and ${ }^{2}$ Medical, Surgical Sciences \\ and Advanced Technologies 'G.F. Ingrassia', University of Catania, I-95123 Catania, Italy
}

Received January 31, 2017; Accepted March 9, 2017

DOI: $10.3892 / \mathrm{mmr} .2017 .6409$

\begin{abstract}
A wide body of evidence indicates that environmental and occupational risk factors are associated with the development of pathological disorders. The pathogenic role of many environmental pollutants or occupational contaminants is already known and has been extensively investigated. However, the molecular mechanisms of action and the pathogenic effects of many substances remain unknown. Therefore, there is a need to better investigate the role of new environmental and occupational risk factors that may cause the development of several diseases.

The association between occupational risk factors and diseases has been studied since 1700. Percivall Pott was the pioneer of observational studies on occupational risk factors and tumor development. In the second half of the 18th century, Pott demonstrated how the rate of incidence of testicular cancer was higher in London chimney sweepers compared to the general population. These findings were explained by the poor hygienic conditions of these workers; following persistent exposure to ash, they developed tumors (1). Subsequently, with the advances of scientific knowledge on the role of the environment in public health, other risk factors have been identified and well characterized, in fact, several premature deaths are due firstly to ischemic heart disease and stroke caused by outdoor air pollution, secondly are due to chronic obstructive pulmonary disease or acute lower respiratory tract infections and, finally, lung cancer (2). Some air pollutants, such as heavy metals or polycyclic aromatic hydrocarbons (PAHs), have been considered certain risk factors for the development of a number of pathologies (3), including neoplastic diseases $(4,5)$ but also the excess of classic pollutants such as NOx, PM10,
\end{abstract}

Correspondence to: Professor Salvatore Santo Signorelli, Department of Clinical and Experimental Medicine, University of Catania, Via Santa Sofia 78, I-95123 Catania, Italy

E-mail: ssignore@unict.it

Key words: occupational exposure, disease, risk factors, cancer, prevention
PM2.5 and SO2 are related to high mortality in particular also in urban environment $(6,7)$.

Different molecular mechanisms induced by such environmental and occupational risk factors have been identified. In the case of heavy metals, one of the main mechanisms of action is represented by the interaction between these elements and enzymatic activities involved in cell functioning (8). Other substances, such as PAHs, mineral fibers, biological agents (viruses and bacteria), pesticides, air pollutants (PM10 particulates, radon gas and chlorofluorocarbons) are able to directly interact with DNA and determine driver mutations that lead to neoplastic transformation (9-19).

The Special Issue entitled 'Environmental and occupational risk factors associated with different pathological conditions' aims to provide a broad overview of the gained knowledge about the interaction between environmental and professional risk factors during disease development. The exact characterization of these factors, and their roles in human diseases, may prove to be useful in the identification of novel strategies aimed at reducing such risk factors and, in turn, the disease rate. Accordingly, the issue contains original data and an extensive analysis of the literature, emphasizing the molecular actions of various pollutants at the cellular and systemic level. The roles of heavy metals in deep vein thrombosis, including modifications of oxidative stress markers, kidney failure and cancer are also discussed. In this context, the treatment with propionyl L-carnitine may induce the reduction of such oxidative parameters $(20,21)$. Furthermore, the pathogenic role of volcanic dust and mineral fibers in the context of lung diseases is shown. The toxic effects of lead, benzene and pesticide exposure in workers are also discussed. Such effects may comprise the occurrence of immunologic reaction including the hypersensitivity that can be modulate with different immunosuppressive treatments $(22,23)$. Finally, among the biological occupational risk factors, hepatitis $\mathrm{C}$ virus (HCV) infection is also described as one of the main factors responsible for extrahepatic manifestations.

According to the contents of this issue, it is clear that in addition to the already known lifestyle habits (24), the environmental and occupational exposure to several hazardous compounds is also linked to the development of several chronic degenerative diseases, including cancer. The pathogenic 
mechanisms of oncogenic transformation are often caused by the activation of several pathways, such as p53, Raf/MEK/ERK and PI3K/AKT (21-25). Based on these data, additional studies are required in order to determine and characterize the type of contaminants and the estimated exposure values that lead to the development of pathologies. Epidemiological registries and environmental data on the association between specific risk factors and the development of diseases may be of utmost importance, ensuring a better health surveillance and a more effective evaluation of the risks in exposed individuals.

\section{References}

1. Brown JR and Thornton JL: Percivall Pott (1714-1788) and chimney sweepers' cancer of the scrotum. Br J Ind Med 14: 68-70, 1957.

2. Oliveri Conti G, Heibati B, Kloog I, Fiore M and Ferrante M: A review of AirQ Models and their applications for forecasting the air pollution health outcomes. Environ Sci Pollut Res Int: Jan 4, 2017 (Epub ahead of print). doi: 10.1007/s11356-016-8180-1.

3. Chiarugi A, Pitari GM, Costa R, Ferrante M, Villari L, Amico-Roxas M, Godfraind T, Bianchi A and Salomone S: Effect of prolonged incubation with copper on endothelium-dependent relaxation in rat isolated aorta. Br J Pharmacol 136: 1185-1193, 2002.

4. Soltani N, Keshavarzi B, Moore F, Tavakol T, Lahijanzadeh AR, Jaafarzadeh $\mathrm{N}$ and Kermani M: Ecological and human health hazards of heavy metals and polycyclic aromatic hydrocarbons (PAHs) in road dust of Isfahan metropolis, Iran. Sci Total Environ 505: 712-723, 2015.

5. Sankpal UT, Pius H, Khan M, Shukoor MI, Maliakal P, Lee CM, Abdelrahim M, Connelly SF and Basha R: Environmental factors in causing human cancers: Emphasis on tumorigenesis. Tumour Biol 33: 1265-1274, 2012.

6. Miri M, Derakhshan Z, Allahabadi A, Ahmadi E, Oliveri Conti G, Ferrante $M$ and Aval HE: Mortality and morbidity due to exposure to outdoor air pollution in Mashhad metropolis, Iran. The AirQ model approach. Environ Res 151: 451-457, 2016.

7. Ghanbari Ghozikali M, Heibati B, Naddafi K, Kloog I, Oliveri Conti G, Polosa R and Ferrante M: Evaluation of Chronic Obstructive Pulmonary Disease (COPD) attributed to atmospheric $\mathrm{O}_{3}, \mathrm{NO}_{2}$, and $\mathrm{SO}_{2}$ using Air Q Model (2011-2012 year). Environ Res 144: 99-105, 2016.

8. Jaishankar M, Tseten T, Anbalagan N, Mathew BB and Beeregowda KN: Toxicity, mechanism and health effects of some heavy metals. Interdiscip Toxicol 7: 60-72, 2014.

9. Alicandro G, Rota M, Boffetta P and La Vecchia C: Occupational exposure to polycyclic aromatic hydrocarbons and lymphatic and hematopoietic neoplasms: A systematic review and meta-analysis of cohort studies. Arch Toxicol 90: 2643-2656, 2016.

10. Liu B, Xue Z, Zhu X and Jia C: Long-term trends (1990-2014), health risks, and sources of atmospheric polycyclic aromatic hydrocarbons (PAHs) in the U.S. Environ Pollut 220: 1171-1179, 2017.

11. Falzone L, Marconi A, Loreto C, Franco S, Spandidos DA and Libra M: Occupational exposure to carcinogens: Benzene, pesticides and fibers (Review). Mol Med Rep 14: 4467-4474, 2016

12. Pandey P, Patel DK, Khan AH, Barman SC, Murthy RC and Kisku GC: Temporal distribution of fine particulates $\left(\mathrm{PM}_{2 \cdot 5}: \mathrm{PM}_{10}\right)$, potentially toxic metals, PAHs and Metal-bound carcinogenic risk in the population of Lucknow City, India. J Environ Sci Health A Tox Hazard Subst Environ Eng 48: 730-745, 2013.
13. Jostes RF: Genetic, cytogenetic, and carcinogenic effects of radon: A review. Mutat Res 340: 125-139, 1996.

14. Hernández AF and Menéndez P: Linking Pesticide Exposure with Pediatric Leukemia: Potential Underlying Mechanisms. Int J Mol Sci 17: 461, 2016.

15. Rapisarda V, Loreto C, Ledda C, Musumeci G, Bracci M, Santarelli L, Renis M, Ferrante M and Cardile V: Cytotoxicity, oxidative stress and genotoxicity induced by glass fibers on human alveolar epithelial cell line A549. Toxicol In Vitro 29: 551-557, 2015.

16. Signorelli SS, Fatuzzo P, Rapisarda F, Neri S, Ferrante M, Oliveri Conti G, Fallico R, Di Pino L, Pennisi G, Celotta G, et al: A randomised, controlled clinical trial evaluating changes in therapeutic efficacy and oxidative parameters after treatment with propionyl L-carnitine in patients with peripheral arterial disease requiring haemodialysis. Drugs Aging 23: 263-270, 2006.

17. Santo SS, Sergio N,Luigi DP, Giuseppe M, Margherita F, Gea OC, Roberto F, Gabriella C, Giuseppe P and Massimiliano A: Effect of PLC on functional parameters and oxidative profile in type 2 diabetes-associated PAD. Diabetes Res Clin Pract 72: 231-237, 2006.

18. Donia M, Mangano K, Quattrocchi C, Fagone P, Signorelli S, Magro G, Sfacteria A, Bendtzen K and Nicoletti F: Specific and strain-independent effects of dexamethasone in the prevention and treatment of experimental autoimmune encephalomyelitis in rodents. Scand J Immunol 72: 396-407, 2010.

19. Mangano K, Nicoletti A, Patti F, Donia M, Malaguarnera L, Signorelli S, Magro G, Muzio V, Greco B, Zaratin P, et al: Variable effects of cyclophosphamide in rodent models of experimental allergic encephalomyelitis. Clin Exp Immunol 159: 159-168, 2010.

20. Polesel J, Franceschi S, Talamini R, Negri E, Barzan L, Montella M, Libra M, Vaccher E, Franchin G, La Vecchia C, et al: Tobacco smoking, alcohol drinking, and the risk of different histological types of nasopharyngeal cancer in a low-risk population. Oral Oncol 47: 541-545, 2011

21. Bagnoli M, De Cecco L, Granata A, Nicoletti R, Marchesi E, Alberti P, Valeri B, Libra M, Barbareschi M, Raspagliesi F, et al: Identification of a chrXq27.3 microRNA cluster associated with early relapse in advanced stage ovarian cancer patients. Oncotarget 6: 9643, 2015.

22. McCubrey JA, Steelman LS, Franklin RA, Abrams SL, Chappell WH, Wong EW, Lehmann BD, Terrian DM, Basecke J, Stivala F, et al: Targeting the RAF/MEK/ERK, PI3K/AKT and p53 pathways in hematopoietic drug resistance. Adv Enzyme Regul 47: 64-103, 2007.

23. Sokolosky ML, Stadelman KM, Chappell WH, Abrams SL, Martelli AM, Stivala F, Libra M, Nicoletti F, Drobot LB, Franklin RA, et al: Involvement of Akt-1 and mTOR in sensitivity of breast cancer to targeted therapy. Oncotarget 2: 538-550, 2011.

24. McCubrey JA, Abrams SL, Ligresti G, Misaghian N, Wong EW, Steelman LS, Bäsecke J, Troppmair J, Libra M, Nicoletti F, et al: Involvement of p53 and Raf/MEK/ERK pathways in hematopoietic drug resistance. Leukemia 22: 2080-2090, 2008.

25. Gangemi S, Miozzi E, Teodoro M, Briguglio G, De Luca A, Alibrando C, Polito I and Libra M: Occupational exposure to pesticides as a possible risk factor for the development of chronic diseases in humans (Review). Mol Med Rep 14: 4475-4488, 2016. 